\title{
COMPARATIVE STUDIES OF DICTYNA AND MALLOS \\ (ARANEAE, DICTYNIDAE): \\ III. PREY AND PREDATORY BEHAVIOR
}

\author{
BY ROBERT R. JACKSON* \\ North Carolina Division of Mental Health Services \\ Research Section, P. O. Box 7532 \\ Raleigh, N. C. 27611
}

\begin{abstract}
INTRODUCTION
Although spiders are a major group of predaceous arthropods (see Turnbull, 1973), the types of prey consumed in their natural habitats are known for relatively few species. Some of the more noteworthy studies have employed daily monitoring of webs of araneids (Robinson and Robinson, 1970) and immunological techniques with lycosids (Greenstone, 1978); however, very little information is available for the dictynids. There is particular interest in the diet of dictynids because different species in this family live under a variety of types of social organization (Jackson, 1978). Discussions of the prime movers in the evolution of social phenomena frequently emphasize the type of prey taken by social predators (Wilson, 1975). An important factor for some species (e.g., army ants, canids, and killer whales) seems to be the ability of groups of individuals acting together to handle relatively large and dangerous prey. In order to evaluate the importance of this factor in the evolution of social phenomena in spiders, we need information concerning the diet and predatory behavior of species with differing types of social organization.

The species in this study belong to the closely related genera, Mallos and Dictyna. These are small cribellate spiders (body length usually $5 \mathrm{~mm}$ or less). Observations of actual feeding and other behavior related to predation were made in the western United States of America in June and July, and in south-central Mexico in September. Additional observations were made in the labora-
\end{abstract}

*Present address: Department of Zoology, University of Canterbury, Christchurch

1, New Zealand.

Manuscript received by the editor January 15, 1978. 
tory. Also, arthropod carcasses in webs were collected and identified. Data are given as means \pm S.D.

Most dictynid species are solitary, each individual generally living alone in an individual web that does not touch other occupied webs. Communal, territorial species ( $M$. trivittatus Banks, D. albopilosa Franganillo, D. calcarata Banks) live in web complexes, consisting of web units connected to each other by silk. M. gregalis Simon (communal, non-territorial) lives in communal webs not subdivided into web units. Aggressive and cannibalistic behavior are virtually non-existent in this species, and individuals routinely feed in groups on the same prey. The other species are aggressive and cannibalistic, and most often they feed one spider per prey. In this paper basic information concerning the feeding behavior and diet of varied species will be presented, and a specific hypothesis will be discussed: namely, is predation on relatively large and dangerous prey an important factor in $M$. gregalis? Other aspects of the feeding behavior of $M$. gregalis have been reported elsewhere (Burgess, 1975; Jackson, 1979a; Witt, et al., 1978).

Data concerning $M$. gregalis were gathered in conjunction with another study (Jackson, 1979a) to which the reader should refer for a description of laboratory methods. "Large webs" were communal webs built on plants in the laboratory, each probably containing several hundred spiders (Jackson and Smith, 1979); and these were not enclosed. "Small webs" (built by four spiders each) and "singlefemale webs" were built inside plastic cages. Data concerning where the spider first grasped the fly came from all three types of webs; data concerning size and composition of feeding groups came from large webs only.

\section{DIET}

Diptera were the predominant prey upon which Dictyna and Mallos were observed feeding (Table 1), and these dominated the collection of carcasses (Table 2). The data in Table 2 should be viewed as a list of probable rather than certain prey of these species, since some were possibly not fed upon by the dictynids. Two small Diptera in webs of $M$. niveus and one small Diptera in a web of $D$. tridentata were still filled with hemolymph. Probably these were captured flies on which the spiders had not yet fed completely. this species came from spending many hours observing a particular 
Table 1. Number of instances of dictynids feeding on different types of prey listed according to their estimated relative sizes (prey size/spider size). When more than one individual fed on the same prey item (M. trivittatus), relative prey size based on largest spider.

\begin{tabular}{|c|c|c|c|c|c|}
\hline \multirow[t]{2}{*}{ Species } & \multirow[t]{2}{*}{ Type of Prey } & \multicolumn{4}{|c|}{ Number of Prey } \\
\hline & & $\begin{array}{c}\text { Smaller } \\
\text { than } \\
\text { Spider }\end{array}$ & $\begin{array}{l}\text { Same } \\
\text { size as } \\
\text { Spider }\end{array}$ & $\begin{array}{l}\text { Larger } \\
\text { than } \\
\text { Spider }\end{array}$ & Total \\
\hline Dictyna calcarata & Diptera & 0 & 1 & 2 & 3 \\
\hline Dictyna completa & Diptera & 0 & 2 & 1 & 3 \\
\hline Dictyna phylax & Diptera & 2 & 0 & 0 & 2 \\
\hline Dictyna tridentata & Diptera & 1 & 1 & 0 & 2 \\
\hline Mallos dugesi & Diptera & 0 & 1 & 0 & 1 \\
\hline Mallos niveus & Diptera & 2 & 0 & 0 & 2 \\
\hline \multirow[t]{3}{*}{ Mallos trivittatus } & Diptera $^{a}$ & 25 & 12 & 15 & 52 \\
\hline & Lepidoptera $^{\mathrm{b}}$ & 0 & 0 & 4 & 4 \\
\hline & Conspecific Spider & 0 & 2 & 0 & 2 \\
\hline
\end{tabular}

aTipulidae: 14

Other Diptera: 38

${ }^{\mathrm{b}}$ Moths

My approach to the web may have disturbed the spider, causing it to depart from the prey. A living tipulid caught in a M. trivittatus web will be discussed later. All other carcasses in Table 2 were dry, hollow, and almost entirely intact, which is the usual condition of prey of these spiders after feeding has occurred. Spiders inject enzymes into their prey, and digestion takes place primarily outside the spider's body. The spiders ingest the prey's tissues in fluid form. Unlike some other spiders, no noticeable mastication of the prey occurs with dictynids. Since other species of spiders (salticids, tetragnathids, etc.) frequently were found inside or near webs containing dictynids, possibly some of the arthropod carcasses in Table 2 were prey of these species, but most were probably prey of the dictynids. Predation on conspecifics (cannibalism) is discussed elsewhere (Jackson, 1979b).

\section{CirCadian PATtern of FeEding AND Other ACtivities}

Many more data are available concerning $M$. trivittatus than for the other species. Most of the observations of feeding (88\%) for 
Table 2. Number of arthropod carcasses ("prey remains") found in webs occupied by dictynids. Listed according to their estimated relative sizes (prey size/spider size). When more than one individual dictynid occupied the same web, relative prey size based on largest spider. Unidentified Dictyna: sp. no. 1, Querecho Plains, New Mexico, U.S.A.; sp. no. 2, Whiskey Mountain, Wyoming, U.S.A.; sp. no. 3, Lake Chapala, Jalisco and Michoacan, Mexico.

\begin{tabular}{|c|c|c|c|c|c|}
\hline \multirow[t]{2}{*}{ Species } & \multirow[t]{2}{*}{ Type of Prey } & \multicolumn{3}{|c|}{ Number of Prey } & \multirow[b]{2}{*}{ Total } \\
\hline & & $\begin{array}{l}\text { Smaller } \\
\text { than } \\
\text { Spider }\end{array}$ & $\begin{array}{l}\text { Same } \\
\text { Size as } \\
\text { Spider }\end{array}$ & $\begin{array}{l}\text { Larger } \\
\text { than } \\
\text { Spider }\end{array}$ & \\
\hline $\begin{array}{l}\text { Dictyna albopilosa } \\
\text { Franganillo }\end{array}$ & Diptera & 8 & 5 & 2 & 15 \\
\hline \multirow{2}{*}{$\begin{array}{l}\text { Dictyna annexa } \\
\text { Gertsch \& Chamberlin }\end{array}$} & Diptera & 30 & 16 & 1 & 47 \\
\hline & Coleoptera & 0 & 1 & 0 & 1 \\
\hline \multirow{2}{*}{$\begin{array}{l}\text { Dictyna bellans } \\
\text { Chamberlin }\end{array}$} & Diptera & 2 & 2 & 0 & 4 \\
\hline & Lepidoptera $^{1}$ & 0 & 0 & 1 & 1 \\
\hline \multirow{5}{*}{$\begin{array}{l}\text { Dictyna calcarata } \\
\text { Banks }\end{array}$} & Diptera & 55 & 16 & 4 & 75 \\
\hline & Coleoptera & 0 & 2 & 2 & 4 \\
\hline & Homoptera $^{2}$ & 2 & 0 & 0 & 2 \\
\hline & Hymenoptera $^{3}$ & 0 & 2 & 0 & 2 \\
\hline & Lepidoptera ${ }^{1}$ & 0 & 0 & 1 & 1 \\
\hline \multirow{2}{*}{$\begin{array}{l}\text { Dictyna coloradensis } \\
\text { Chamberlin }\end{array}$} & Diptera & 21 & 1 & 2 & 24 \\
\hline & Hemiptera & 0 & 0 & 1 & 1 \\
\hline $\begin{array}{l}\text { Dictyna completa } \\
\text { Chamberlin \& Gertsch }\end{array}$ & Diptera & 1 & 5 & 1 & 7 \\
\hline \multirow{3}{*}{$\begin{array}{l}\text { Dictyna tridentata } \\
\text { Bishop \& Rudeman }\end{array}$} & Diptera & 42 & 46 & 37 & 125 \\
\hline & Coleoptera & 0 & 0 & 1 & 1 \\
\hline & Hemiptera & 0 & 0 & 1 & 1 \\
\hline $\begin{array}{l}\text { Dictyna phylax } \\
\text { Gertsch \& Ivie }\end{array}$ & Diptera & 9 & 3 & 0 & 12 \\
\hline \multirow[t]{4}{*}{ Dictyna sp. no. 1} & Diptera & 26 & 7 & 0 & 33 \\
\hline & Hymenoptera $^{4}$ & 0 & 0 & 1 & 1 \\
\hline & Lepidotera $^{1}$ & 0 & 0 & 1 & 1 \\
\hline & Conspecific & 1 & 0 & 0 & 1 \\
\hline \multirow[t]{2}{*}{ Dictyna sp. no. 2} & Diptera & 0 & 4 & 4 & 8 \\
\hline & Hymenoptera ${ }^{4}$ & 0 & 0 & 1 & 1 \\
\hline \multirow[t]{2}{*}{ Dictyna sp. no. 3} & Diptera & 7 & 8 & 6 & 21 \\
\hline & Homoptera ${ }^{2}$ & 1 & 0 & 0 & 1 \\
\hline
\end{tabular}




\begin{tabular}{|c|c|c|c|c|c|}
\hline \multirow[t]{2}{*}{ Species } & \multirow[t]{2}{*}{ Type of Prey } & \multicolumn{3}{|c|}{ Number of Prey } & \\
\hline & & $\begin{array}{c}\text { Smaller } \\
\text { than } \\
\text { Spider }\end{array}$ & $\begin{array}{l}\text { Same } \\
\text { Size as } \\
\text { Spider }\end{array}$ & $\begin{array}{c}\text { Larger } \\
\text { than } \\
\text { Spider }\end{array}$ & Total \\
\hline $\begin{array}{l}\text { Mallos dugesi } \\
\text { Becker }\end{array}$ & Diptera & 3 & 1 & 2 & 6 \\
\hline $\begin{array}{l}\text { Mallos niveus } \\
\text { O. P. Cambridge }\end{array}$ & $\begin{array}{l}\text { Diptera } \\
\text { Coleoptera } \\
\text { Homoptera }^{2} \\
\text { Hymenoptera }^{4} \\
\text { Orthoptera }^{5} \\
\text { Thysanoptera } \\
\text { Salticid spider }\end{array}$ & $\begin{array}{c}57 \\
0 \\
0 \\
0 \\
0 \\
2 \\
0\end{array}$ & $\begin{array}{c}38 \\
3 \\
1 \\
1 \\
0 \\
0 \\
0\end{array}$ & $\begin{array}{c}18 \\
2 \\
0 \\
2 \\
1 \\
0 \\
1\end{array}$ & $\begin{array}{r}113 \\
5 \\
1 \\
3 \\
1 \\
2 \\
1\end{array}$ \\
\hline $\begin{array}{l}\text { Mallos trivittatus } \\
\text { Banks }\end{array}$ & $\begin{array}{l}\text { Diptera }^{6} \\
\text { Coleoptera } \\
\text { Homoptera }^{2} \\
\text { Hymenoptera }^{3} \\
\text { Lepidoptera } \\
\text { Neuroptera } \\
\text { Conspecific }\end{array}$ & $\begin{array}{r}163 \\
1 \\
3 \\
1 \\
0 \\
1 \\
2\end{array}$ & $\begin{array}{r}20 \\
0 \\
0 \\
0 \\
11 \\
0 \\
3\end{array}$ & $\begin{array}{r}38 \\
0 \\
0 \\
0 \\
5 \\
0 \\
0\end{array}$ & $\begin{array}{r}221 \\
1 \\
3 \\
1 \\
16 \\
1 \\
5\end{array}$ \\
\hline
\end{tabular}

\footnotetext{
${ }^{1}$ Moth

${ }^{2}$ Aphid

${ }^{3}$ Ant

${ }^{4}$ Wasp

${ }^{5}$ Grasshopper nymph

${ }^{6}$ Tipulidae: 33

Other Diptera: 188
}

web complex, located in a culvert through which a creek passed in the Chiracahua Mountains of Arizona. This large web complex was estimated to contain more than 10,000 individuals of $M$. trivittatus (Jackson and Smith, 1979). Since initial observations suggested that feeding occurred predominantly in the late afternoon and early evening (see below), one hour was spent inside the culvert on each of 12 evenings ( 5 in June; 7 in July); and records were kept for all observed cases of feeding. Diptera and other insects in the vicinity were especially active at this time of the day, and this was generally true in other habitats of $M$. trivittatus and the other dictynids. 
Table 3. Temporal pattern of activity of spiders in their natural habitats. Time of day: early morning and early evening, within $2 \mathrm{hr}$ before and after sunrise and sunset, respectively. Duration of observation estimated. Walking: without spinning and exclusive of intraspecific interactions. Intraspecific interactions described elsewhere. (Jackson, 1979b). Dictyna phylax and Mallos dugesi observed in day only.

\begin{tabular}{|c|c|c|c|c|c|c|}
\hline 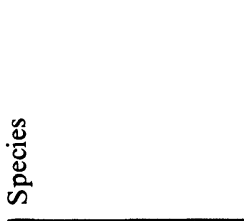 & 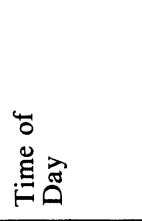 & 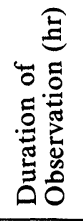 & 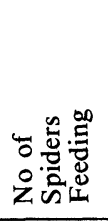 & 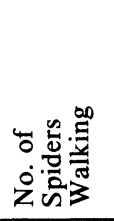 & 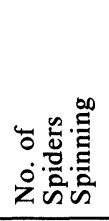 & 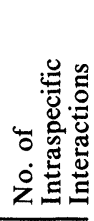 \\
\hline \multirow[t]{3}{*}{ Dictyna calcarata } & $\begin{array}{l}\text { Early } \\
\text { Morning }\end{array}$ & 3 & 2 & 5 & 6 & 1 \\
\hline & Day & 5 & 0 & 0 & 0 & 0 \\
\hline & $\begin{array}{l}\text { Early } \\
\text { Evening }\end{array}$ & 2 & 1 & 0 & 0 & 0 \\
\hline \multirow[t]{3}{*}{ Dictyna completa } & $\begin{array}{l}\text { Early } \\
\text { Morning }\end{array}$ & 2 & 1 & 0 & 0 & 0 \\
\hline & Day & 4 & 2 & 0 & 0 & 0 \\
\hline & $\begin{array}{l}\text { Early } \\
\text { Evening }\end{array}$ & 2 & 0 & 0 & 1 & 0 \\
\hline Dictyna phylax & Day & 6 & 2 & 0 & 0 & 0 \\
\hline \multirow[t]{3}{*}{ Dictyna tridentata } & $\begin{array}{l}\text { Early } \\
\text { Morning }\end{array}$ & 6 & 1 & 2 & 0 & 2 \\
\hline & Day & 14 & 0 & 0 & 0 & 0 \\
\hline & $\begin{array}{l}\text { Early } \\
\text { Evening }\end{array}$ & 4 & 1 & 0 & 0 & 0 \\
\hline Mallos dugesi & Day & 7 & 1 & 0 & 0 & 0 \\
\hline \multirow[t]{3}{*}{ Mallos niveus } & $\begin{array}{l}\text { Early } \\
\text { Morning }\end{array}$ & 5 & 0 & 0 & 0 & 0 \\
\hline & Day & 14 & 2 & 0 & 0 & 0 \\
\hline & $\begin{array}{l}\text { Early } \\
\text { Evening }\end{array}$ & 5 & 0 & 0 & 2 & 1 \\
\hline \multirow[t]{3}{*}{ Mallos trivittatus } & $\begin{array}{l}\text { Early } \\
\text { Morning }\end{array}$ & 17 & 0 & 3 & 0 & 0 \\
\hline & Day & 34 & 3 & 0 & 0 & 0 \\
\hline & $\begin{array}{l}\text { Early } \\
\text { Evening }\end{array}$ & 19 & 53 & 18 & 3 & 9 \\
\hline
\end{tabular}


With the exception of the evening observations in the culvert, the amount of time spent observing webs was recorded only approximately. These estimates were used for the calculations in Table 3. Based on these data, it seems that feeding and general activity of the dictynids in this study occur predominantly in the evening.

\section{INITIAL CONTACT OF SPIDER WITH PREY}

Certain spiders, such as some araneids and theridiids, wrap their prey either before and/or after biting; however, this does not occur in the Dictynidae. These spiders seem to simply rush out and bite the prey. If the prey is violently struggling, the spider may walk or stand in the vicinity until activity subsides.

Bristowe (1958) reported that dictynids invariably grasp their prey initially by a leg. The initiation of feeding was seen for one $M$. niveus and five $M$. trivittatus. In each case, the spider initially grasped a leg or antenna of the prey. Of the spiders already feeding when found, some were feeding on the head, thorax, or abdomen of the prey (Fig. 1), although data were not recorded. M. gregalis, $M$. trivittatus, $M$. niveus, and D. calcarata were maintained and fed in the laboratory, and it was noted that the spiders sometimes initially grasped the prey by its head or body rather than by an appendage. For $M$. gregalis in the laboratory, the location at which the spider first grasped the prey was recorded for 66 individuals: leg, 44\%; head, 15\%; abdomen, 14\%; thorax, 11\%; wing, 9\%; antenna, $7 \%$. All of these flies were active when contacted.

Once I saw an opilionid walk onto a web unit containing an adult female $M$. trivittatus. The spider rushed out of its nest and grasped a leg of the opilionid with its chelicerae. Immediately, the spider released the opilionid and returned to its nest, suggestive of opilionids being distasteful to dictynids (see Bristowe, 1941). Several minutes later, the opilionid escaped from the web.

\section{EXTENSION LINES}

Webs of $M$. trivittatus frequently contain long, heavy lines of silk (extension lines) that extend to objects some distance from the mesh (Jackson, 1978). Once in Utah I found an extension line fastened at one end to a mesh, with a female $M$. trivittatus inside the nest. On the other end, a tipulid fly was tethered by its thorax. 


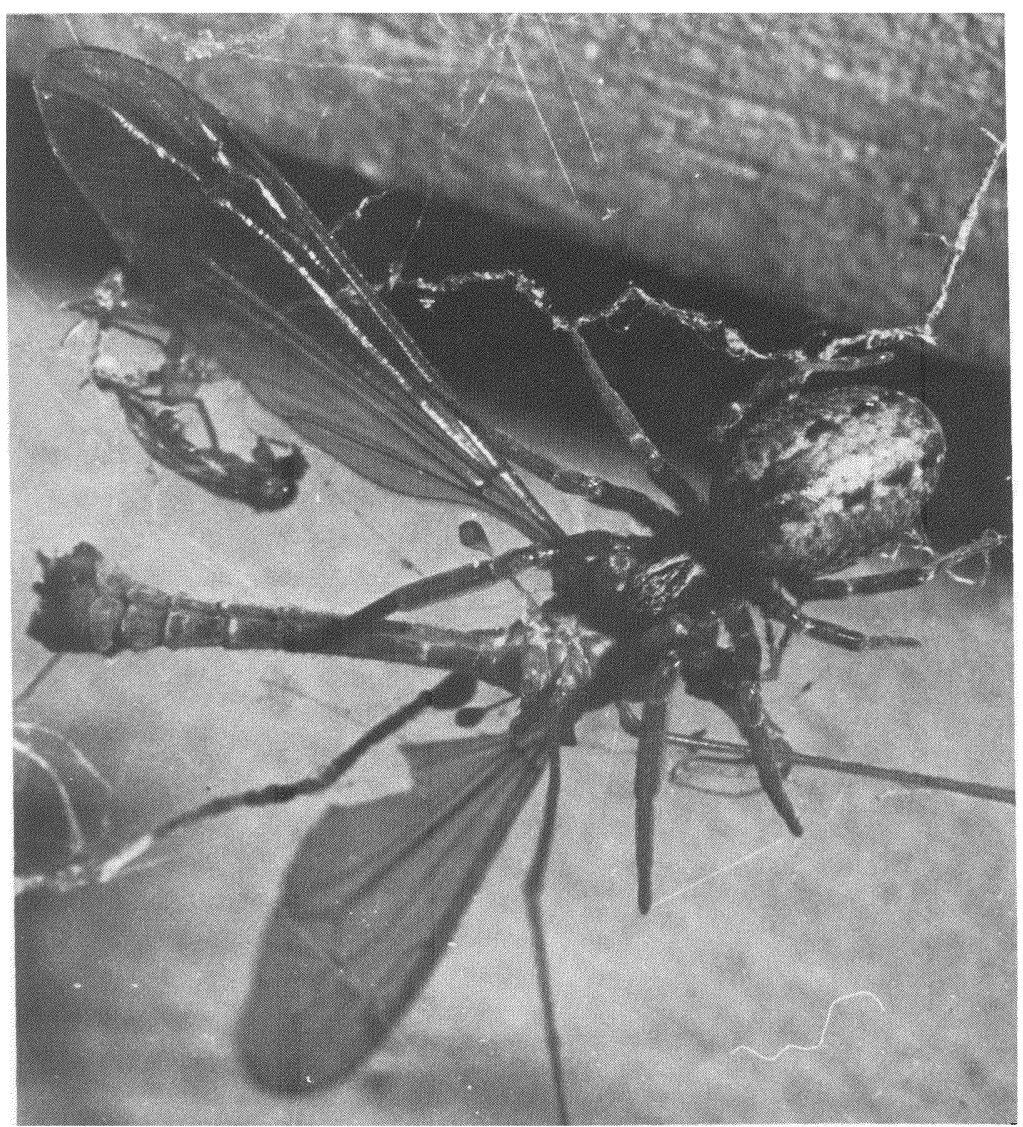

Fig. 1. Adult female Mallos trivittatus (body length: $7 \mathrm{~mm}$ ) at East Turkey Creek (Chiracahua Mountains, Arizona) feeding on tipulid fly. Fly grasped at ventral thorax.

The tipulid flew in circles continuously for 10 min while I observed, after which I collected the fly and the spider. Of the set of $M$. trivitattus observed feeding in nature, $9 \%$ were on extension lines at the time; and 5\% of the arthropod carcasses found in webs of $M$. trivittatus were found on extension lines. M. gregalis webs also have extension lines, and these spiders sometimes fed on flies caught on extension lines. 


\section{FEEDING GROUPS - SIZE AND COMPOSITION}

The few cases in which more than one spider fed on the same prey in species other than $M$. gregalis are described elsewhere (Jackson, 1979b). In the laboratory, the size and composition of the group feeding on the fly was recorded $15 \mathrm{~min}$ after it contacted the web, and cases in which no spiders were feeding at the end of the $15 \mathrm{~min}$ are excluded. Group size was $4.8 \pm 2.96$ spiders (range: $1-15 ; n=38$ ). In the cases in which a single spider fed on the fly, three were females, two were immatures, and none were males. One of the immatures was a second instar; the other was almost adult size. In cases in which more than one spider fed on the fly, there were three groups consisting of females only; 4, immatures only; 21 , females and immatures but no males; 2 , males and immatures but no females; and 3, females, males, and immatures. In more casual observations, single males feeding on flies and groups consisting of females and males but no immatures were seen; but groups of more than one male but no females or immatures were not noticed. Groups of more than 20 individuals have been seen.

\section{DISCUSSION}

Based on arthropod carcasses found in webs and observations of actual feeding in nature, Diptera seem to constitute the major prey of the closely related species of Dictyna and Mallos in this study. Billaudelle (1957), Bristowe (1958), and Wiehle (1953) commented on dictynids preying on Diptera, ants, and lice. Unfortunately, only limited information is available concerning the natural prey of $M$. gregalis, the communal, non-territorial species. I was not able to find this species when I was in Mexico. Diguet (1909a, b, $1915)$ and Burgess (1976 and personal communication) noted that Diptera seem to be the primary prey of this species in nature, although wasps are also fed upon. The Diptera seem to be predominantly ones of body lengths of approximately 5 to $10 \mathrm{~mm}$, such as the "domestic fly" (presumably Musca domestica), tabanids, and bot flies. Burgess collected a portion of a web in Mexico; and when examined in the laboratory, it contained a great number of carcasses, all of Diptera in the size range of 5 to $10 \mathrm{~mm}$. In the laboratory, $M$. gregalis has thrived for several years on a diet of $M$. domestica almost exclusively. The natives of Michoacan have 
given this species the name el mosquero. During the rainy season, they take portions of communal webs from trees and place these in and around their homes, using them as fly traps (Berland, 1913; Diguet, 1909a, b, 1915; Gertsch, 1949).

Burgess (1975) has demonstrated that vibrations within a frequency range comparable to the wing beat frequency of Musca domestica is the most effective stimulus for eliciting predatory behavior from $M$. gregalis. Furthermore, the web transmits vibrations within this frequency range more readily than ones with other frequency characteristics. It seems that the web has characteristics that are particularly appropriate for the predominant prey species. The vibration transmission properties of webs of other species have not been investigated yet.

Some Diptera may be captured when they fly into Dictyna and Mallos webs. However, it was noticed that many Diptera tend to land on the stems and leaves of herbs and shrubs, on rock ledges, and on other objects on which dictynids tend to build their webs. Perhaps the majority of Diptera are captured when they inadvertently use a web as a perch. Musca domestica were frequently captured, seemingly in this manner, on webs of $M$. gregalis in the laboratory. These webs were kept in the open, on plants and other objects, in the laboratory. During routine feeding, house flies were thrown into the communal webs, but many inadvertently escaped into the room beforehand. Frequently these were seen subsequently landing on the webs and adhering to the silk. Thrown flies would seem more comparable to flying Diptera, and there is no evidence that the ratio of flies captured to ones that escaped differed for flies landing on the web compared to ones thrown into the web (Jackson, 1979a).

The extension lines in webs of $M$. gregalis and $M$. trivittatus may have a function related to predation. Diptera may find them to be particularly attractive perches and become trapped when they land on them. Another cribellate species, Miagrammopes (Uloboridae) has a single thread snare, and it reportedly captures Diptera that use the thread as a perch (Akerman, 1932).

Dictynid webs have nests, which are tubular structures of more densely woven silk; and the spiders tend to reside in their nests when not active. Spiders in various families (e.g., Agelenidae, Eresidae, Dysderidae) which have nests in their webs often transport prey to the nest before feeding(see Bristowe, 1958; Krafft, 1971). Araneid 
spiders tend to transport prey to the hub of the web before feeding (Robinson and Olazarri, 1971). Although data were not collected, it was noticed that arthropod carcasses tended to be concentrated near the nests of the solitary and the communal, territorial species; and many of the feeding dictynids were near their nests at the time. These observations suggest that dictynids transport prey to their nests, although actual transport has not been seen. Billaudelle (1957) noted that $D$. civica carries prey from the periphery to the center of the web.

Most dictynid webs tend to be 2-dimensional; i.e., most of the silk of the web is in a single plane. In contrast, the communal webs of $M$. gregalis tend to be 3-dimensional; and the nests are in the interior of the webs, beneath the surface sheet on which flies are captured. Although flies were occasionally pulled into the interior of webs by spiders, in the vast majority of cases the prey was fed upon at the capture site in communal webs in the laboratory.

Returning to the hypothesis proposed at the beginning of this paper, is the prey of $M$. gregalis relatively large and dangerous compared to that of other dictynids? Diptera are apparently the primary prey of most species. Since Diptera such as muscids, culicidids, etc. would not seem especially dangerous for dictynids, differences in the danger associated with different prey would not seem important. Adult females of $M$. gregalis, the largest sex/age class, tend to weigh 4 to $21 \mathrm{mg}$, adult $M$ usca domestica tend to weigh 10 to $20 \mathrm{mg}$ (Witt, et al., 1978). If prey of M. gregalis is in this weight range, then prey tends to range from approximately equal in size to individual spiders to a few times larger. In the solitary and in the communal, territorial species, prey were often smaller than the spiders. However, the difference in relative prey size among species is not absolute. Many prey of solitary and communal, territorial species were equal to or larger in size than the spiders (see also Bristowe, 1958; Wiehle, 1953).

Since prey sizes overlap for different dictynids, we need quantitative data from which variances can be calculated for relative prey size. Data from the natural habitats of $M$. gregalis in Mexico are especially needed. It will be tentatively concluded that $M$. gregalis preys primarily on relatively large prey. However, the differences in relative prey size do not seem dramatic. In a sense, the social organization of $M$. gregalis seems very different from that of the other dictynids, with great numbers of spiders living and feeding 
together in the same communal webs. If diet is a major factor in the evolution of social phenomena in dictynid spiders, we might expect the diet of $M$. gregalis to differ greatly from that of other dictynids. Although differences in prey size seem to occur, perhaps the most interesting finding in this study is that there is considerable overlap in prey sizes of different dictynids. We need to consider the possibility that predation on relatively large and dangerous prey is only one among other equally or more important factors acting as prime movers in the evolution of social phenomena in the Dictynidae and perhaps for other groups as well.

\section{SUMMARY}

Based on arthropod carcasses in webs and observations of actual feeding, Diptera seems to be the major prey of Dictyna and Mallos. $M$. gregalis, a species that routinely feeds in groups, may tend to prey upon relatively large prey compared to the other species. However, relative prey sizes overlap for species of all types of social organization. No apparent differences occur in the degree to which prey are dangerous. These observations are not to be expected from the hypothesis that the prime mover in the evolution of social phenomena in spiders is the ability of predators acting as a group to handle relatively large and dangerous prey. Although legs of flies are frequently grasped first, M. gregalis may initially grasp almost any part of the fly. Size of feeding groups varies greatly, ranging from 1 to more than 20 . The hypothesis is proposed that prey is captured by Dictyna and Mallos primarily when flies use webs as resting sites. Feeding and other activity occur especially in the early evening and early morning.

\section{ACKNOWLEDGEMENTS}

For valuable discussions and comments on the manuscript, I would like to thank P. N. Witt, M. C. Vick, S. E. Smith, and J. W. Burgess. Special thanks go to W. J. Gertsch for his assistance in the identification of spiders. C. E. Griswold, P. S. Jackson, and V. D. Roth are gratefully acknowledged for helping me locate spiders in the field. The assistance of the Southwestern Research Station of the American Museum of Natural History is gratefully 
acknowledged. Thanks go to R. B. Daniels for typing the manuscript. This work was supported in part by the North Carolina Division of Mental Health Services, Research Section and by N.S.F. grant number BMS $75-09915$ to P. N. Witt.

\section{REFERENCES}

AKerman, C.

1932. On the spider Miagrommopes sp which constructs a single line snare. Ann. Natal Mus. 7: 1-7.

BERLAND, L.

1913. Utilisation pour la capture des Mouches, des nids de l'Araignée mexicaine Coenothele gregalis E. Simon. Bull. Mus. hist. nat. 1913: 432-433. Billaudelle, $\mathrm{H}$.

1957. Zur Biologie der Mauerspinne Dictyna civica (H. Luc.) (Dictynidae, Araneida). Z. Angew. Entomol. 41: 475-512.

BRistowe, W. S.

1941. The comity of spiders. Vol. II. London: Ray Society. 560 pp.

1958. The world of spiders. London: Collins. $304 \mathrm{pp}$.

Burgess, J. W.

1975. The sheet web as a transducer, modifying vibration signals in social spider colonies of Mallos gregalis. Neurosci. Abstr.: 557.

1976. Social spiders. Sci. Amer. 234: 100-106.

DigueT, L.

1909a. Sur l'Araignée mosquero. C. R. Acad. Sci., Paris 148: 735-736.

1909b. Le mosquero. Bull. Soc. Acclim. France 56: 368-375.

1915. Nouvelles observations sur le mosquero ou nid d'Araignées sociales employé comme piège a mouches dans certaines localités du Mexique. Bull. Soc. Acclim. France 62: 240-249.

GERTSCH, W. J.

1949. American spiders. Princeton: Van Nostrand. 285 pp.

GREENSTONE, M.

1978. Non-density-dependent predation and maintenance of a mixed diet in a field population of the wolf spider, Pardosa ramulosa. Symp. Zool. Soc. Lond. In press.

JACKSON, R. R.

1978. Comparative studies of Dictyna and Mallos (Araneae: Dictynidae): I. Social organization and web characteristics. Rev. Arachnol., in press.

1979a. Predatory behavior of the social spider Mallos gregalis: Is it cooperative? In prep.

1979b. Comparative studies of Dictyna and Mallos (Araneae: Dictynidae): II. The relationship between courtship, mating, aggression and cannibalism in species with differing types of social organization. In prep.

JACKSON, R. R. AND S. E. SMITH

1979. Aggregations of Mallos and Dictyna (Araneae, Dictynidae): Population characteristics. In prep. 
KRAFFT, B.

1971. Contribution à la biologie et l'Ethologie d'Agelena consociata Denis (Araignée sociale du Gabon). Troisieme Partie. Etude expérimentale de certains phenomenes sociaux. Biol. Gabon. 7: 3-56.

Robinson, M. H. AND J. OlazarRi

1971. Units of behavior and complex sequences in the predatory behavior of Argiope argentata (Fabricius): (Araneae: Araneidae). Smiths. Contrib. Zool. 65: 1-36.

RoBINSON, M. H. AND B. RoBINSON

1970. Prey caught by a sample population of the spider Argiope argentata (Araneae: Araneidae) in Panama: a year's census data. Zool. J. Linn. Soc. 49: 345-357.

TURnBull, A. L.

1973. Ecology of the true spiders (Araneomorphae). Ann. Rev. Entomol. 18: 305-348.

WIEHLE, $\mathrm{H}$.

1953. Spinnentiere oder Arachnoidea (Araneae) IX. Orthognatha-CribellateHaplogynae-Entelegynae (Pholcidae, Zodariidae, Oxyopidae, Mimetidae, Nesticidae). In: Die Tierwelt Deutschlands (F. Dahl, ed.) Jena: Fischer.

WILSON, E. O.

1975. Sociobiology. Cambridge, Massachusetts: Belknap. 697 pp.

Witt, P. N., M. B. Scarboro, and D. B. Peakall

1978. Comparative feeding data in three spider species of different sociality: Araneus diadematus $\mathrm{Cl}$., Mallos trivittatus Banks and Mallos gregalis Simon. Symp. Zool. Soc. Lond. In press. 

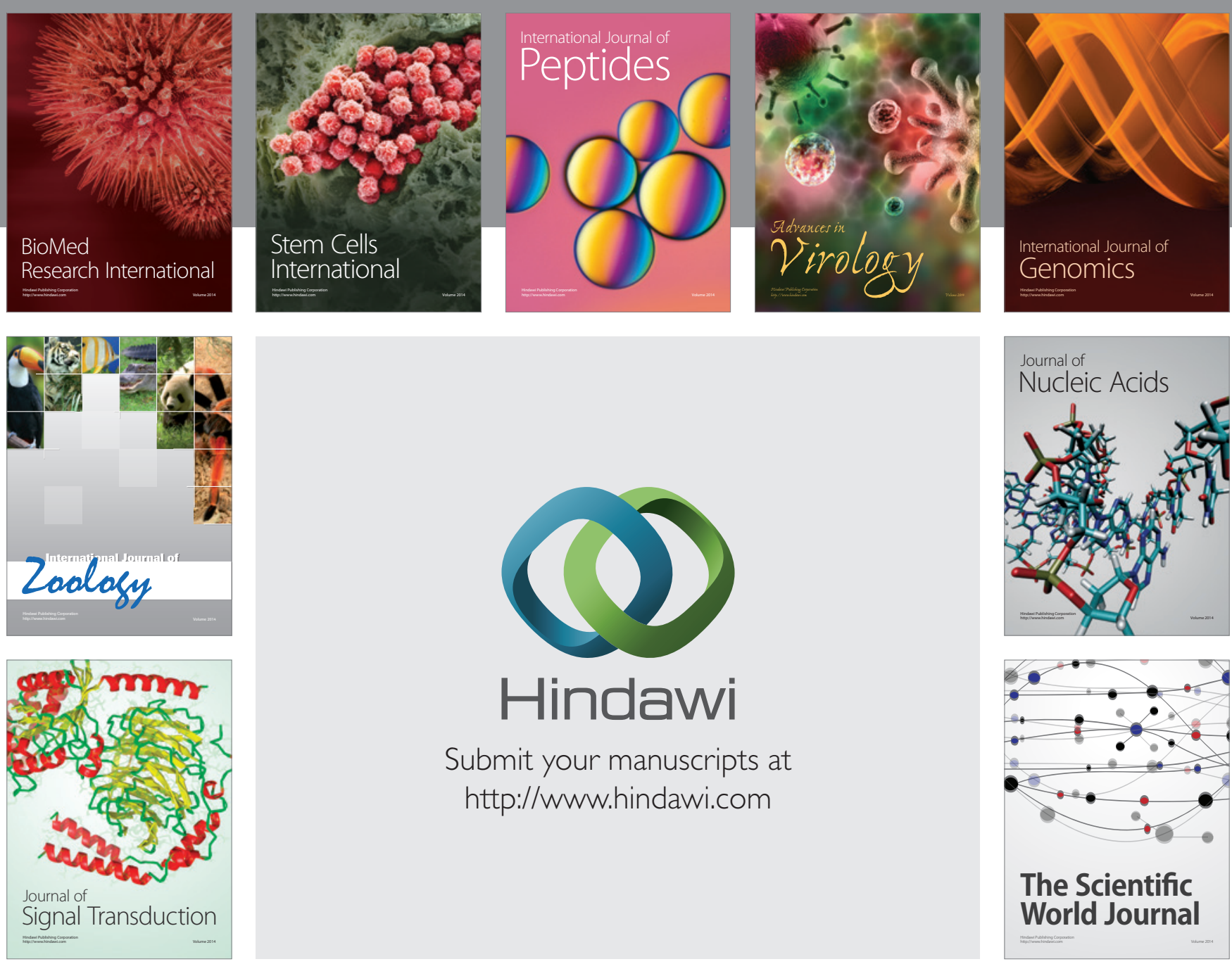

Submit your manuscripts at

http://www.hindawi.com
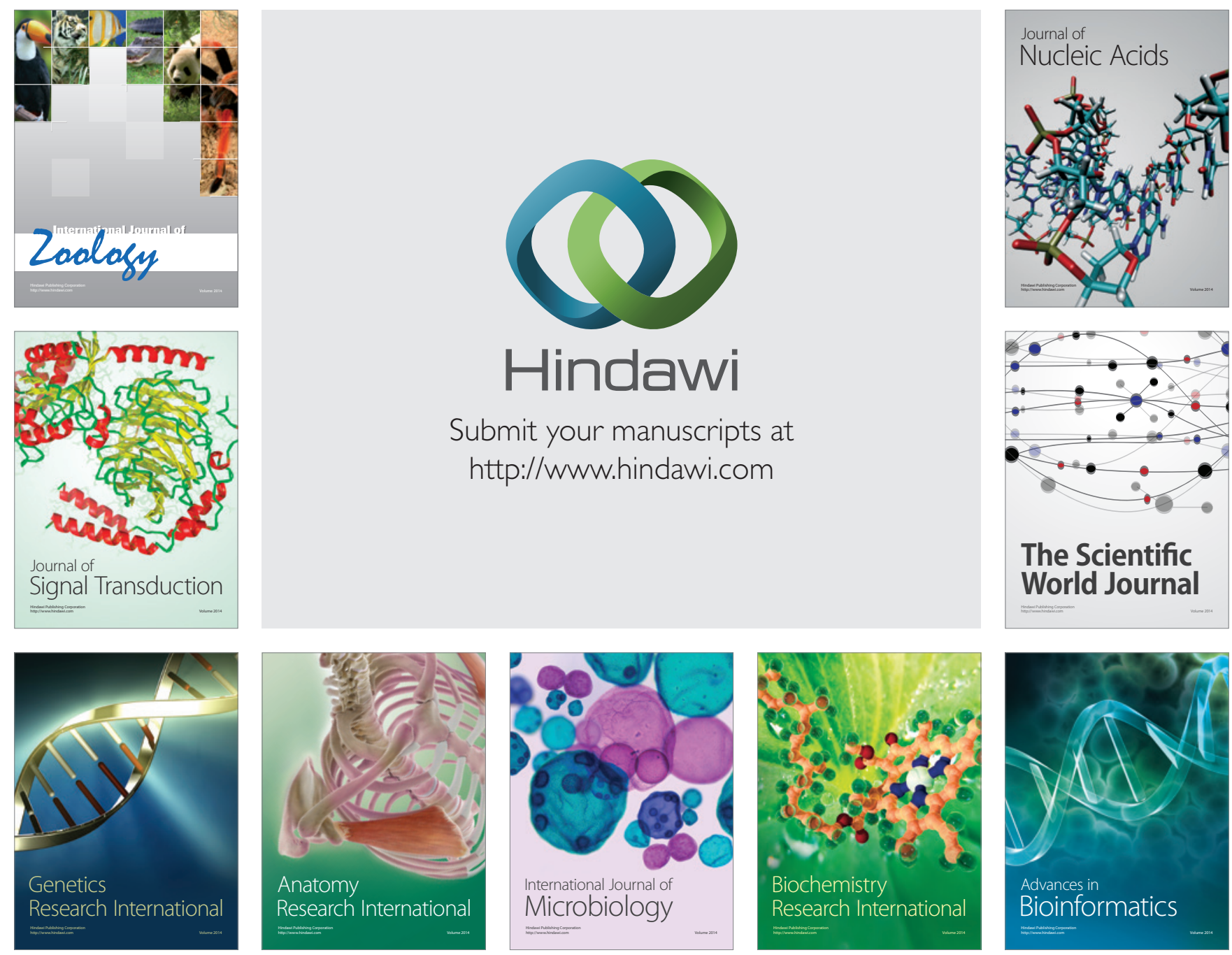

The Scientific World Journal
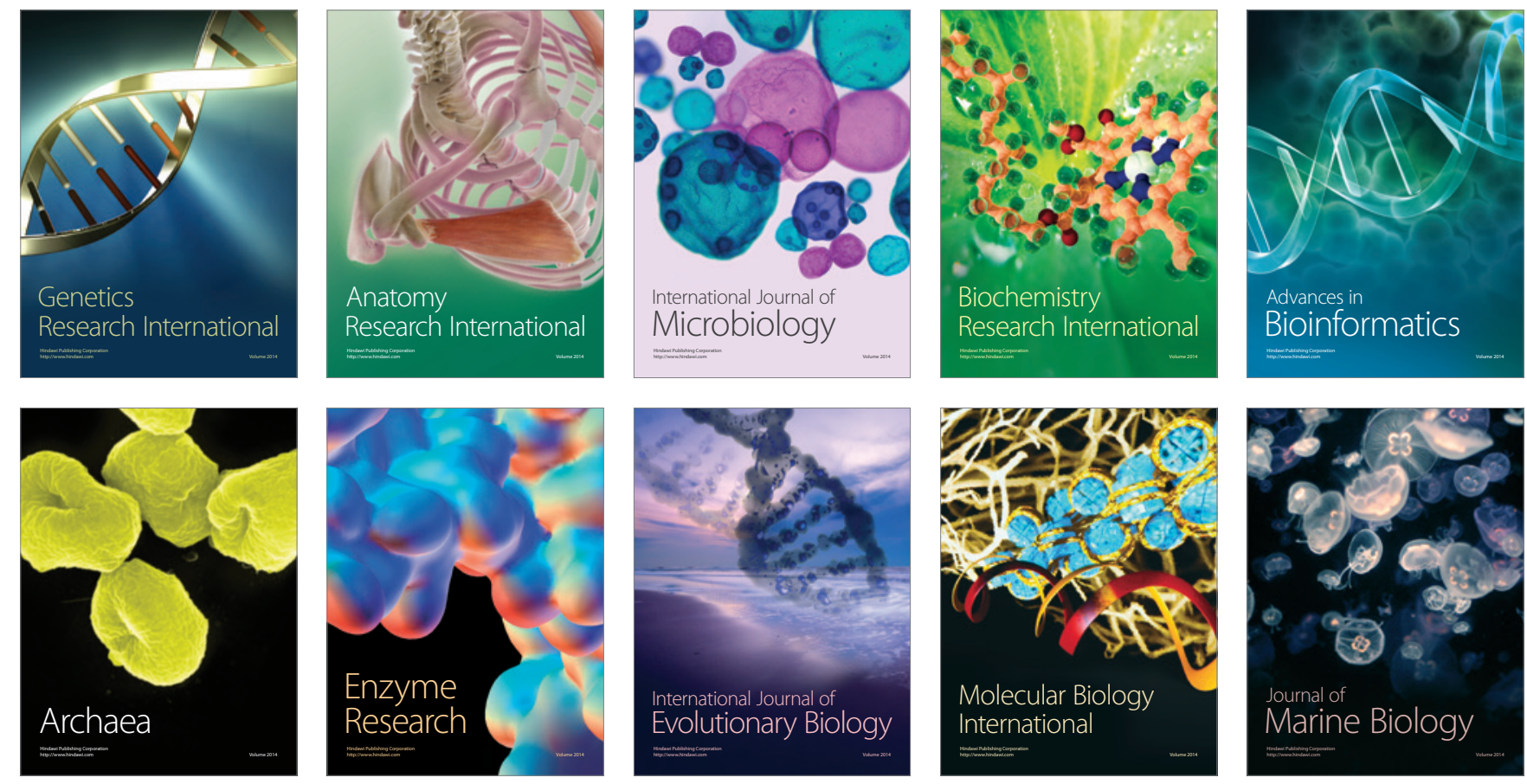